\title{
A retenção nos cursos de graduação do IME/UFG
}

\author{
Chaiane de Medeiros Rosa* \\ Fabiano Fortunato Teixeira dos Santos**
}

\begin{abstract}
Resumo
Este estudo buscou compreender o fenômeno da retenção nos cursos do Instituto de Matemática e Estatística da Universidade Federal de Goiás. Para tanto, foi realizada uma pesquisa quanti-qualitativa, com base em microdados fornecidos pela Pró-Reitoria de Graduação, dados do Sistema Integrado de Gestão de Atividades Acadêmicas, além de respostas a um questionário eletrônico aplicado aos alunos retidos. Como resultado, este estudo revelou que a retenção está relacionada a múltiplos fatores, como: vulnerabilidade socioeconômica; dificuldade de conciliar trabalho e estudo; problemas didáticos/pedagógicos por parte dos professores; excesso de reprovações; alto nível de exigência; e elevado grau de dificuldade do curso.

Palavras-chave: Retenção; Matemática; Estatística; Instituto de Matemática e Estatística; Universidade Federal de Goiás.
\end{abstract}

\section{The retention in IME/UFG graduation courses}

\begin{abstract}
This study aimed to understand the phenomenon of retention in the courses of the Institute of Mathematics and Statistics of the Federal University of Goiás. Therefore, a quantitative-qualitative research was made, based on microdata provided by the Pro-Rectory of Graduation, datas from the Integrated Management System of Academic Activities, as well as answers to an electronic questionnaire applied to retained students. As a result, this study revealed that retention is related to multiple factors, such as: socioeconomic vulnerability; difficulty in reconciling work and study; teaching/pedagogical problems on the part of teachers; excess of reproofs; high level of requirement; and high degree of difficulty of course.

Keywords: Retention; Mathematics; Statistic; Institute of Mathematics and Statistics; Federal University of Goiás.
\end{abstract}

\section{Introdução}

A ampliação do acesso à educação superior tornou-se pauta das políticas públicas educacionais, sobretudo a partir dos anos 2000. Desde então, uma série de ações foram propostas para atingir esse escopo, como: o Fundo de Financiamento do Estudante de Ensino Superior (Fies), criado em 2001, voltado para a concessão de financiamento a estudantes de instituições privadas; o Programa Universidade para Todos (Prouni), criado em 2005, com a finalidade de ofertar bolsas de estudos para estudantes de instituições privadas; a expansão da educação à distância por meio da Universidade Aberta do Brasil (UAB), criada em 2006, com o escopo de expandir e interiorizar a oferta de cursos e programas de educação superior; o Reuni, criado em 2007, com o objetivo de criar condições para ampliação do acesso e permanência na educação superior; a expansão da educação profissional e tecnológica pela criação da Rede Federal de Educação Profissional, Científica e Tecnológica e dos Institutos Federais de Educação, Ciência e Tecnologia (IFs) em 2008; o Plano Nacional de

*E-mail: chaianemr@hotmail.com

**E-mail: fabianoftds@yahoo.com.br
Assistência Estudantil (Pnaes), criado em 2010 com a finalidade de ampliar as condições de permanência na educação superior; e a Lei n. ${ }^{\circ} 12.711$ de 2012, a lei de cotas, que estabelece reserva de vagas no acesso à educação superior para minorias étnicas e sociais da população brasileira.

Nesse contexto de ampliação das oportunidades educacionais, é emergente pensar a formação dos estudantes em sua amplitude, considerando, entre outros aspectos, a permanência dos mesmos nas instituições de ensino. E, nesse bojo, um problema que se apresenta é a retenção. Segundo o Dicionário Online de Português, retenção significa: permanência; estado ou condição do que se mantém, do que permanece; ato ou efeito de reter, de conservar.

Vieira (2013) esclarece que há duas abordagens para se tratar de retenção. Uma a entende como fenômeno positivo, pois significa manter o estudante em seu quadro; e a outra o concebe como o fato de o estudante ficar preso, retido na grade curricular, e, logo, saindo do fluxo concebido como ideal. Neste estudo, entende-se por retenção na educação superior a permanência prolongada do 
aluno no curso de graduação, o atraso na conclusão de sua formação.

Essa problemática merece ser estudada visto que, de acordo com Pereira et al. (2015, p. 1016), "[...] compromete a taxa de sucesso, gera ociosidade de recursos humanos e materiais e pode provocar a evasão do estudante". Campello e Lins (2008) argumentam que os prejuízos da retenção estão em não permitir que os alunos formados possam atuar nas suas respectivas áreas do conhecimento no prazo inicialmente previsto. Além do que, esses alunos, em algum momento, podem se evadir. No mais, os autores chamam a atenção para o fato que:

Este fato [retenção] força a sociedade a arcar com o ônus de manter indivíduos sem o devido retorno do investimento que ela despendeu em sua formação. Dessa forma, por meio da chamada matrícula-vínculo ou da matrícula em poucas disciplinas, o aluno consegue permanecer vinculado ao curso, ocupando uma vaga pública que poderia ter sido mais bem aproveitada. (CAMPELLO; LINS, 2008, p. 03)

Portanto, é notório que a retenção culmina em perdas de recursos públicos, mas também perdas sociais, de oportunidades que poderiam ser melhor aproveitadas pelos estudantes matriculados; ou por outros, que ficaram excluídos no processo de ingresso na educação superior, mas ambicionam uma vaga.

Na Universidade Federal de Goiás (UFG), o quadro de alunos retidos é bastante expressivo. Dos ingressantes de 2006 a 2009, um pequeno percentual de estudantes ainda está ativo: 0,1\% de 2006 e 2007; $1,2 \%$ de 2008; e 2,7\% de 2009. Já dos ingressantes de 2010, 7,6\% ainda estão ativos. Do grupo dos ingressantes a partir de 2011, o percentual de ativos é maior, sendo de $16,3 \%$ em 2011; 29,6\% em 2012; $52 \%$ em 2013; 61,2\% em 2014; 57,5\% em 2015 e $65,3 \%$ em 2016. O elevado percentual de alunos ainda ativos, sobretudo a partir de 2013, explica-se pelo fato de que o prazo regular para integralização dos cursos de graduação na universidade varia de quatro a cinco anos, a depender do curso. Sendo assim, é natural que uma parcela dos ingressantes a partir de 2013 ainda esteja ativa. Todavia, o número de alunos ingressantes de 2006 a 2012 na UFG, e ainda ativos, revela um quadro de alunos retidos, que são aqueles que não concluíram o curso no período mínimo regular.

A retenção, que culmina no prolongamento do curso, é uma problemática nacional. Pesquisa realizada por Vanz et al. (2016), sobre a evasão e retenção no curso de Biblioteconomia da Universidade Federal do Rio Grande do Sul (UFRGS), identificou mais de $40 \%$ de alunos com extremo atraso. Do mesmo modo, estudo de Pereira et al. (2015) evidenciou, na Universidade Federal do Espírito Santo (UFES), uma retenção de 52,2\%, dos estudantes que deveriam se formar nos cursos de graduação presencial da referida universidade do segundo semestre de 2007 ao primeiro semestre de 2012.

De acordo com Pereira (2013),

A retenção no ensino superior é uma expressão utilizada para se referir ao processo que resulta na permanência prolongada do estudante em um curso de graduação. A amplitude do conceito permite inferir o desenvolvimento de diversos elementos no processo, dos quais se destacam as reprovações e os trancamentos de curso, além da possibilidade de atraso voluntário por parte do aluno no cumprimento da carga horária prevista na matriz curricular do curso. (PEREIRA, 2013, p. 17)

Pereira et al. (2015) explicam que a retenção se trata de um problema que se manifesta em diversas perspectivas: causando prejuízos pessoais, profissionais e financeiros aos estudantes; comprometendo e eficiência e produtividade do sistema de ensino, bem como a taxa de conclusão e ocupação de vagas; gerando custos adicionais à instituição; e reduzindo o retorno à sociedade, por atrasar a disponibilização de cidadãos habilitados para o mercado de trabalho.

Isso posto, é importante que cada instituição, considerando suas peculiaridades, elabore indicativos próprios, com base em registros acadêmicos dos alunos, de modo a compreender os fatores mais significativos que levam à retenção e evasão em seu próprio contexto. A partir de então, torna-se possível a elaboração de políticas institucionais eficazes para combater essas problemáticas, que são indissociáveis. (LIMA JÚNIOR; SILVEIRA; OSTERMANN, 2012) Por isso, este estudo, ao delinear o perfil dos estudantes em situação de retenção no Instituto de Matemática e Estatística (IME) da UFG, torna-se elementar para fornecer subsídios para a propositura de ações voltadas para evitar essa problemática.

\section{Delineamento Metodológico}

É importante dizer que este artigo é resultado de uma pesquisa em andamento no IME/UFG com o 
escopo de compreender os contornos do acesso, retenção e evasão nos cursos da unidade, bem como entender os condicionantes desses últimos processos, que resultam em fracasso escolar. Para a realização da pesquisa referenciada, os alunos do IME/UFG, que frequentam os cursos de Matemática (bacharelado e licenciatura) e Estatística (bacharelado), foram divididos em três grupos: excluídos, retidos e regulares. Para cada um deles, foi aplicado um questionário online específico.

Neste estudo, em especial, foca-se na análise e compreensão da retenção. Para tanto, foi realizada uma pesquisa de abordagem quanti-qualitativa, que se vale de vários instrumentos para compreender o fenômeno investigado. Essa escolha metodológica se respalda na compreensão de Gondim (2012), segundo a qual:

A unidade pelo método é insuficiente, não garante $\mathrm{o}$ preenchimento das lacunas do conhecimento. O método é um meio através do qual as proposições teóricas buscam evidências lógicas, empíricas e insigths necessários para a interpretação. Há pelo menos quatro fundamentos da conduta humana: o físico, o biológico, o cognitivo e o social. São níveis de entendimento diferenciados, o que não significa que um tenha status superior aos demais, mas que oferecem limites de explicação distintos, pois partem de premissas e pressupostos variados. Se se pretende unidade na ciência social a tolerância para com as abordagens diversificadas é um primeiro passo. (GONDIM, 2002, p. 151)

Esta pesquisa, portanto, analisa dados quantitativos, que consistem em microdados fornecidos pela Pró-Reitoria de Graduação (Prograd) da UFG, de 2006 a 2016, e também dados consultados no Sistema Integrado de Gestão de Atividades Acadêmicas (Sigaa) da universidade. Neste estudo, foram considerados os dados dos estudantes com ingresso até o primeiro semestre de 2013, visto que, desses, os alunos da Matemática já deveriam ter concluído o curso no segundo semestre de 2016, e os alunos ingressantes da Estatística até esse ano deveriam ter concluído o curso no primeiro semestre de $2017^{1}$. Nesse aspecto, as categorias analisadas foram as seguintes: alunos ativos por ano de ingresso, e graduados por semestre de inativação.

Além desses dados numéricos, com vistas a construir uma análise e interpretação também qualitativa, foi aplicado um questionário eletrônico aos alunos retidos dos cursos do IME no primeiro semestre de 2017, com vistas a colher informações de cunho mais subjetivo, baseadas nas impressões dos alunos sobre as questões que lhes foram apresentadas. Foram enviados questionários a 131 alunos da unidade, sendo 63 alunos da Matemática licenciatura, 21 da Matemática - bacharelado e 47 da Estatística - bacharelado. O percentual de respostas foi de $41,3 \%, 47,5 \%$ e $55,2 \%$, respectivamente, de modo que, no total, 62 alunos responderam, o que representa $47,3 \%$ do total. Nesse campo, as questões voltaram-se para a compreensão das seguintes questões: primeira opção de curso de graduação; motivação para a escolha do curso; intencionalidade de mudar de curso; renda familiar e atividade laboral/acadêmica; tempo de dedicação aos estudos; acesso aos professores para tirar dúvidas fora do horário regular das aulas; participação em atividades acadêmicas extracurriculares; número de reprovações; grau de dificuldade atribuída ao curso; número de trancamentos; e dificuldades enfrentadas no curso.

Neste estudo, portanto, o que se busca é a compreensão da retenção para além de sua manifestação quantitativa, de modo que se possa compreender, também, os aspectos pessoais, sociais e situacionais envolvidos no processo de permanência prolongada nos cursos de graduação do IME/UFG. Sendo assim, acredita-se que métodos quantitativos e qualitativos, quando conjugados, permitem que a compreensão e análise do fenômeno estudado não sejam enviesados para apenas uma característica ou outra, mas se tornem mais abrangentes, e, logo, significativas.

\section{Desenvolvimento}

No IME/UFG, há um quadro significativo de alunos que já ultrapassaram o período regular de integralização curricular, mas que ainda estão ativos, ou seja, em situação de retenção, como demonstrado abaixo. 
TABELA 1: Evolução do número de alunos ativos nos cursos do IME por ano de ingresso - 2006/2016

\begin{tabular}{c|c|c|c|c|c|c|c|c|c}
\hline & \multicolumn{3}{|l|}{ Matemática - licenciatura } & \multicolumn{3}{l|}{ Matemática - bacharelado } & \multicolumn{3}{|c}{ Estatística - bacharelado } \\
\hline $\begin{array}{c}\text { Ano de } \\
\text { ingresso }\end{array}$ & Ingressantes & Ativos & $\%$ & Ingressantes & Ativos & $\%$ & Ingressantes & Ativos & $\%$ \\
\hline 2008 & 65 & 1 & 1,5 & 16 & 1 & 6,3 & - & - & - \\
\hline 2009 & 63 & - & - & 7 & - & - & 33 & 1 & 3,0 \\
\hline 2010 & 31 & 6 & 19,4 & 11 & 1 & 9,1 & 40 & 2 & 5,0 \\
\hline 2011 & 21 & 5 & 23,8 & 6 & 1 & 16,7 & 28 & 4 & 14,3 \\
\hline 2012 & 58 & 21 & 36,2 & 14 & 7 & 50,0 & 40 & 11 & 27,5 \\
\hline 2013 & 66 & 20 & 30,3 & 12 & 7 & 58,3 & 40 & 11 & 27,5 \\
\hline
\end{tabular}

Fonte: Os autores

Dos alunos da Matemática - licenciatura em situação de retenção, que são os que ingressaram de 2008 a $2013^{2}$, em média $22,2 \%$ estavam retidos. No curso de Matemática - bacharelado, a média de alunos retidos foi maior, de $28,1 \%$ dos ingressantes do mesmo período. Comparando os dados da licenciatura com os do bacharelado, o percentual de alunos retidos neste apenas foi menos que naquele em dois anos: 2010 e 2011. Nos demais períodos, o percentual de retidos no bacharelado foi significativamente maior. Isso pode se explicar pelo grau de dificuldade que normalmente é atribuído ao bacharelado. O curso de Matemática - bacharelado é mais voltado para a continuidade da carreira acadêmica, ao passo que o curso de Matemática - licenciatura forma professores para a educação básica. Por isso, o bacharelado tem em sua grade curricular disciplinas mais abstratas e densas, ao passo que a licenciatura é marcada por disciplinas de caráter mais pedagógico. Já no curso de Estatística bacharelado, a média de retenção dos ingressantes de 2009 a 2013 foi de $15,5 \%$. No curso em questão, não houve alunos ingressantes e/ou ativos em anos anteriores, porque 2009 foi o primeiro ano do curso no IME/UFG.

O panorama traçado mostra que os alunos demoram mais que o período regular para integralizar o curso. Isso pode ser confirmado pelo tempo de permanência dos mesmos na graduação, evidenciado a seguir:

TABELA 2: Ingressantes de 2006 a 2016 graduados, por semestre de inativação - Matemática - IME/UFG

\begin{tabular}{|c|c|c|c|c|c|c|c|c|c|c|c|c|}
\hline $\begin{array}{l}\text { Ano de } \\
\text { ingresso }\end{array}$ & $\begin{array}{c}\text { Total de } \\
\text { graduados }\end{array}$ & $\begin{array}{l}\text { Até 8. } \\
\text { período }\end{array}$ & $90^{\circ}$ & $10 .^{\circ}$ & $11 .^{\circ}$ & $12 .^{\circ}$ & $13 .^{\circ}$ & $14 .^{\circ}$ & $15 .^{\circ}$ & $16^{\circ}$ & $17 .^{\circ}$ & $18 .^{\circ}$ \\
\hline 2006 & 45 & 23 & 0 & 13 & 1 & 5 & 2 & 1 & 0 & 0 & 0 & 0 \\
\hline 2007 & 52 & 29 & 1 & 7 & 6 & 2 & 2 & 2 & 1 & 1 & 0 & 1 \\
\hline 2008 & 33 & 18 & 1 & 7 & 1 & 0 & 1 & 5 & 0 & 0 & 0 & 0 \\
\hline 2009 & 17 & 4 & 2 & 5 & 0 & 1 & 3 & 1 & 0 & 1 & 0 & 0 \\
\hline 2010 & 16 & 6 & 2 & 4 & 0 & 1 & 2 & 1 & 0 & 0 & 0 & 0 \\
\hline 2011 & 10 & 4 & 1 & 1 & 1 & 3 & 0 & 0 & 0 & 0 & 0 & 0 \\
\hline 2012 & 9 & 5 & 1 & 3 & 0 & 0 & 0 & 0 & 0 & 0 & 0 & 0 \\
\hline 2013 & 7 & 7 & 0 & 0 & 0 & 0 & 0 & 0 & 0 & 0 & 0 & 0 \\
\hline Total & 189 & 96 & 8 & 40 & 9 & 12 & 10 & 10 & 1 & 2 & $\mathbf{0}$ & 1 \\
\hline
\end{tabular}

Fonte: Os autores

No curso de Matemática, no período observado, houve alunos que levaram 18 semestres para concluir o seu curso, mais que o dobro do período regular. No geral, em média, $50,8 \%$ dos alunos concluíram o curso no período regular, até o oitavo semestre; $4,2 \%$ terminaram no semestre subsequente; $21,2 \%$ concluíram no décimo período; $4,8 \%$ no décimo primeiro semestre; $6,3 \%$ no décimo segundo período de curso; $5,3 \%$ no décimo terceiro e também no décimo quarto período; e 2,1\% levaram do décimo quinto ao décimo oitavo semestre de curso para se formar. Desse grupo de alunos, 97,9\% 
estavam graduados até o décimo quarto período de curso, três anos após o prazo regular.

No período observado, os anos de 2007, 2008 e 2012 tiveram os maiores percentuais de graduação no período regular, de $55,8 \%, 54,5 \%$ e $55,5 \%$, respectivamente. $\mathrm{O}$ ano que apresentou menor percentual de concluintes no período regular foi 2009 , com $23,5 \%$. O ano de 2017 foi um caso extremamente atípico, pois, todos os formandos concluíram no prazo regular. Mas esse prazo era o segundo semestre de 2016. Portanto, no primeiro semestre de 2017, período de coleta de dados desta pesquisa, ainda não havia ocorrido outra formatura.

TABELA 3: Ingressantes de 2006 a 2016 graduados, por semestre de inativação - Estatística - IME/UFG

\begin{tabular}{|c|c|c|c|c|c|c|c|c|c|}
\hline $\begin{array}{l}\text { Ano de } \\
\text { ingresso }\end{array}$ & $\begin{array}{c}\text { Total de } \\
\text { graduados }\end{array}$ & $\begin{array}{c}\text { Até 9. } \\
\text { período }\end{array}$ & $\mathbf{1 0 .}^{\mathbf{0}}$ & $\mathbf{1 1 .}^{\mathbf{0}}$ & $\mathbf{1 2 .}^{\mathbf{0}}$ & $\mathbf{1 3 .}^{\mathbf{0}}$ & $\mathbf{1 4 .}^{\mathbf{0}}$ & $\mathbf{1 5 .}^{\mathbf{0}}$ & $\mathbf{1 6 .}^{\mathbf{0}}$ \\
\hline $\mathbf{2 0 0 9}$ & 3 & 0 & 1 & 0 & 0 & 0 & 1 & 0 & 1 \\
\hline $\mathbf{2 0 1 0}$ & 9 & 6 & 0 & 2 & 1 & 0 & 0 & 0 & 0 \\
\hline $\mathbf{2 0 1 1}$ & 3 & 1 & 2 & 0 & 0 & 0 & 0 & 0 & 0 \\
\hline $\mathbf{2 0 1 2}$ & 1 & 1 & 0 & 0 & 0 & 0 & 0 & 0 & 0 \\
\hline Total & $\mathbf{1 6}$ & $\mathbf{8}$ & $\mathbf{3}$ & $\mathbf{2}$ & $\mathbf{1}$ & $\mathbf{0}$ & $\mathbf{1}$ & $\mathbf{0}$ & $\mathbf{1}$ \\
\hline
\end{tabular}

Fonte: Os autores

Já dos 16 alunos que ingressaram de 2009 a 2012 e que concluíram o curso de Estatística, o prazo máximo para integralização observado foi de 16 semestres, sete a mais que o prazo padrão. No geral, $50 \%$ desses alunos concluíram o curso em tempo regular, de nove semestres. Outros 18,7\% levaram um semestre a mais para se formar, tendo finalizado o curso com dez semestres; $12 \%$ concluíram o curso com 11 semestres; e 18,7\% levaram de 12 a 16 semestres para concluir a graduação. Desse grupo de alunos, 87,5\% concluíram o curso até o décimo período do curso, três semestres após o prazo regular. No curso em questão, um diferencial positivo foram os ingressantes de 2010, que, dos nove concluintes, seis terminaram no período regular, o que representa $66,7 \%$. Outro destaque, porém negativo, foi dos ingressantes de 2009, a primeira turma do curso de Estatística do IME, que, dos três únicos formandos, nenhum deles conseguiu concluir no prazo regular.

Observando esses dados dos formandos por ano de ingresso, é importante ponderar que esse panorama ainda pode alterar significativamente. Isso porque o número de alunos ainda ativos no curso, e que podem tanto abandoná-lo como se graduar, é bastante expressivo. Na Matemática - licenciatura, há 63 alunos ativos, que já ultrapassaram o prazo de integralizar o curso; na Matemática - bacharelado são 21 estudantes; e na Estatística - bacharelado 47 discentes.

\section{A Voz dos Alunos Retidos}

Tendo em vista os dados quantitativos acima apresentados, percebeu-se a necessidade de compreender as características comuns aos alunos retidos dos cursos ofertados pelo IME/UFG, bem como conhecer as razões pelas quais eles estendem o tempo de conclusão nos cursos de graduação.

Pelos dados da pesquisa, um problema que desponta ao se observar o perfil dos alunos retidos do IME/UFG é que uma parcela significativa está frequentando um curso que não era sua primeira escolha, visto que $43,5 \%$ dos alunos da unidade não estavam no curso que realmente desejavam. Dos alunos da Matemática - licenciatura que declararam que o curso que fazem não era sua primeira opção, eles mencionaram que tinham interesse nos seguintes cursos: Arquitetura, Economia, Ciências Contábeis, Medicina Veterinária, Ciências da Computação, Engenharia Elétrica, Engenharia da Computação, Engenharia Civil e Engenharia Mecânica. Os alunos da Matemática - bacharelado, por sua vez, tinham interesse em ingressar nos seguintes cursos: Arquitetura, Ciência da Computação, Matemática (licenciatura), Física e Engenharia Elétrica. Já os estudantes da Estatística - bacharelado revelaram ter interesse em: Matemática, Física, Farmácia, Engenharia Civil, Engenharia Ambiental e Engenharia de Produção.

Observa-se que, em sua maioria, as primeiras opções dos alunos que não estão matriculados na sua primeira opção eram cursos mais prestigiados. Mas sua escolha foi condicionada por fatores diversos. Veja: 
GRÁFICO 1: O que o levou a optar pelo curso no qual está matriculado?³

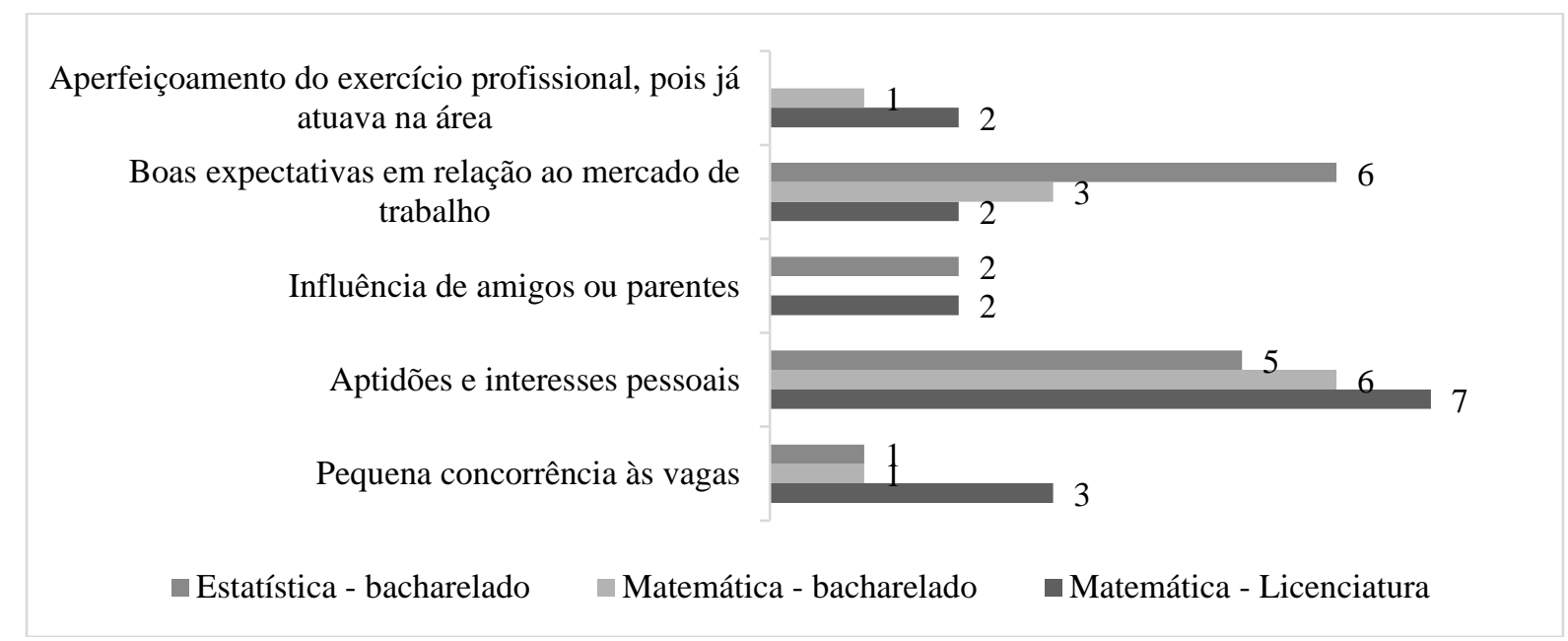

Fonte: Os autores

Do grupo de 16 respostas dos alunos da Matemática - licenciatura, o fator predominante na escolha do curso foi aptidões e interesses pessoais $(43,8 \%)$, seguido do critério pequena concorrência às vagas $(18,7 \%)$, aperfeiçoamento do exercício profissional, pois já atuavam na área $(12,5 \%)$, boas expectativas em relação ao mercado de trabalho $(12,5 \%)$ e influência de amigos ou parentes $(12,5 \%)$. Já as 11 respostas dos alunos da Matemática bacharelado indicaram que o fator que mais influenciou a escolha pelo curso foi aptidões e interesses pessoais $(54,5 \%)$, e, na sequência, aparecem boas expectativas em relação ao mercado de trabalho $(27,3 \%)$, aperfeiçoamento do exercício profissional, pois já atuava na área $(9,1 \%)$ e pequena concorrência às vagas $(9,1 \%)$. Já no curso de Estatística, as 14 respostas sinalizaram que o que mais influenciou as decisões foram as boas expectativas em relação ao mercado de trabalho $(42,9 \%)$, e, depois, as aptidões e interesses pessoais $(35,7 \%)$, a influência de amigos e parentes $(14,3 \%)$ e, por último, a pequena concorrência às vagas $(7,1 \%)$.

Observa-se que, nos cursos de Matemática, a escolha é feita principalmente com base nas aptidões e interesses pessoais. Isso porque, o aluno que apresenta um bom desempenho em Matemática na educação básica, acredita que terá um bom rendimento também na educação superior. Já no curso de Estatística - bacharelado, as expectativas em relação ao mercado de trabalho sobressaíram. Essa atratividade ocorre visto que o mercado da Estatística é crescente e amplo, pois o profissional formado nessa área pode atuar numa diversidade de setores, como: indústria, instituições públicas, bancos, mercado financeiro, seguradora, centros de pesquisa, instituições médicas, e mais.

Também é importante considerar que, mesmo não estando no curso que almejavam, a princípio, os estudantes não apresentaram a intenção de mudar de curso. Dos 62 alunos do IME/UFG que responderam o questionário, apenas $9,7 \%$ disseram ter intenção de mudar de curso. Os alunos da Matemática - bacharelado não manifestaram esse desejo. Já no grupo dos estudantes da Matemática licenciatura, essa vontade foi expressa por $18,2 \%$ dos pesquisados, e na Estatística - bacharelado por 8,3\% dos alunos. Esse panorama pode ser explicado pelo fato de que, como esses alunos já estavam há bastante tempo no curso, tendo inclusive ultrapassado o tempo regular de integralização curricular, eles não se sentiram encorajados a abandoná-lo. No início da graduação, é mais comum que os alunos manifestem interesse de participar de editais internos para concorrer a vagas em outros cursos. Por vezes, eles ingressam em cursos menos concorridos, mas que têm disciplinas afins com as de seu curso de interesse, com a intenção de realizar a mudança e fazer o aproveitamento de alguns créditos.

Mas não se pode desconsiderar o percentual de alunos que, mesmo nesse estágio de adiantamento, apresentaram a intenção de desistir do curso. Quando se trata da desistência, o percentual foi maior em relação à vontade de simplesmente mudar de curso. No geral, dos 62 participantes da pesquisa, 22,6\% manifestaram interesse de desistir da graduação. Esse foi o desejo de 23,1\% dos alunos da Matemática licenciatura, de $10 \%$ dos alunos da Matemática - 
bacharelado e 26,9\% da Estatística - bacharelado. Na Matemática - licenciatura esse potencial de abandono ainda aumentou, posto que $11,5 \%$ dos estudantes disseram que "talvez" pensem na desistência.

Considerando o fato de haver alunos que pretendem mudar ou abandonar o curso, mesmo já tendo ultrapassado o período regular para integralização do curso,

Aqui se pode identificar um alerta à comunidade acadêmica: mesmo que a possibilidade de desapontamento exista para todos os alunos em todos os cursos, é preocupante o fato de que muitos dos alunos estiveram insatisfeitos com sua experiência acadêmica durante boa parte da graduação. Os alunos verbalizaram uma convivência de longo prazo com a dúvida da carreira, a dificuldade de integração acadêmica e o desejo de saída, antes que a evasão fosse implementada [...]. (BARDAGI; HUTZ, 2009, p. 102)

Nesta pesquisa, também foi analisado o perfil social dos alunos, que é o seguinte:

GRÁFICO 2: Qual sua renda familiar?

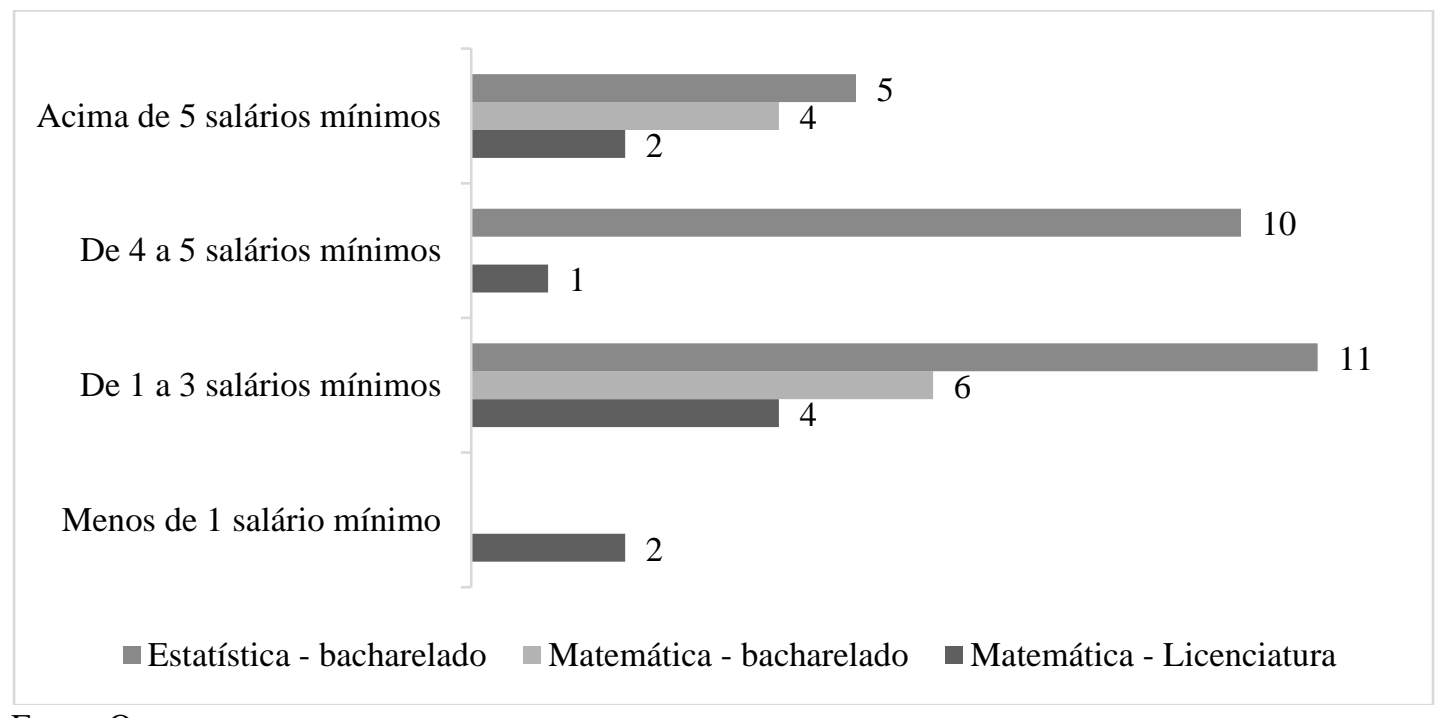

Fonte: Os autores

No geral, o perfil socioeconômico dos alunos retidos dos cursos do IME/UFG são das classes C, D e E, conforme classificação do Instituto Brasileiro de Geografia e Estatística (IBGE) 4 . Porém, há uma diferença quando se considera especificamente cada curso da unidade investigada. Dos alunos da Matemática - licenciatura, dois declararam renda familiar mensal de menos de 1 salário mínimo e 4 de 1 a 3 salários mínimos, o que indica uma situação de extrema fragilidade. Além desses, apenas um afirmou possuir renda familiar de 4 a 5 salários e dois acima de 5 salários. Já no grupo dos alunos da Matemática - bacharelado, não houve nenhum aluno com renda menor que 1 salário mínimo; seis alunos com renda familiar de 1 a 3 salários e quatro acima de 5 salários, o que também não representa uma situação econômica abastada. Já dos alunos da Estatística - bacharelado, o quadro socioeconômico é de 11 alunos que declararam renda familiar mensal de 1 a 3 salários mínimos, dez alunos com renda de 4 a 5 salários, e cinco alunos com renda superior a 5 salários. Portanto, dos cursos observados, Estatística - bacharelado é o que tem o perfil de alunos mais favorecidos, ou, pelo menos, com menos fragilidades de cunho socioeconômico. No lado oposto, os alunos da Matemática - licenciatura são os que se encontram em situação mais vulnerável.

Esse quadro de vulnerabilidade social faz com que muitos sejam, além de estudantes, trabalhadores. É o que demonstra o gráfico a seguir: 
GRÁFICO 3:Que tipo de atividade você exerce?

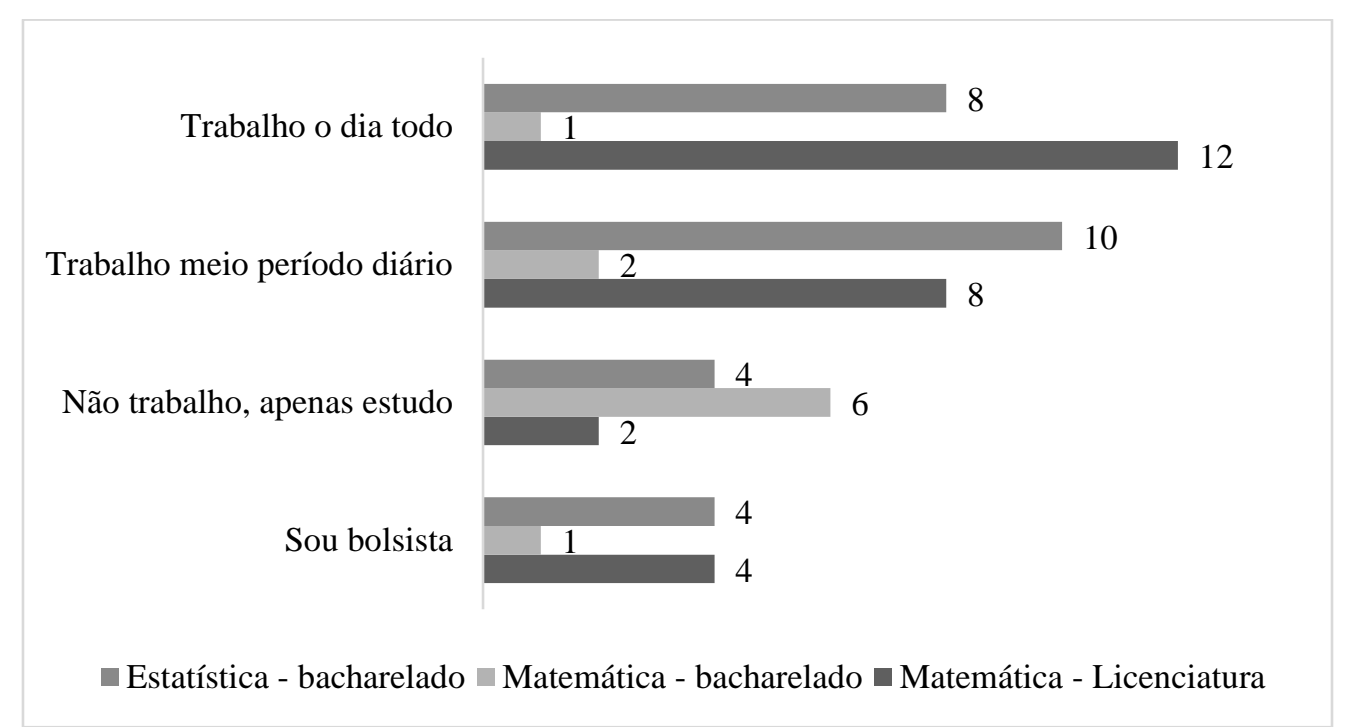

Fonte: Os autores

Dos 62 alunos do IME/UFG que responderam ao questionário, apenas 12 afirmaram que não trabalham, apenas estudam, o que representa $19,4 \%$ do total. Outros 9 estudantes declararam ser bolsistas $(14,5 \%)$ e 41 afirmaram trabalhar $(66,1 \%)$. Dos alunos da Matemática - licenciatura, 12 afirmaram trabalhar o dia todo e 8 apenas meio período diário. Apenas dois desses alunos não trabalhavam, apenas estudam, e quatro eram bolsistas. Do grupo de alunos da Matemática bacharelado, o perfil delineado mostrou-se totalmente diferente, visto que apenas um afirmou trabalhar o dia todo, e dois durante meio período diário. Seis alunos desse curso não trabalhavam, apenas estudavam, e ainda havia um aluno bolsista. Já dos estudantes da Estatística - bacharelado, oito afirmaram trabalhar o dia todo e oito meio período. Nesse curso, quatro alunos declararam apenas estudar, e quatro eram bolsistas.

Logo, dos estudantes da Matemática licenciatura, 76,9\% eram trabalhadores, da Estatística - bacharelado 69,2\% e da Matemática bacharelado apenas 30\%. Esse baixo percentual de estudantes trabalhadores na Matemática bacharelado se relaciona ao fato de o curso ser vespertino. Já os demais cursos, por serem noturnos, possibilitam que os estudantes trabalhem durante o dia e estudem a noite.

Oliveira e Bittar (2010) refletem que o ingresso na educação superior é perpassado por seletividade social, por processos que aniquilam a perspectividade de igualdade de oportunidades para estudantes que buscam seu espaço na vida acadêmica e profissional. E para os estudantes dos cursos noturnos, essa realidade é ainda mais perversa, visto que, para esses alunos que trabalham, o insucesso pode ocorrer por diversos fatores, como:

[...] evadir-se por não conseguir pagar as mensalidades [no caso de instituições privadas]; não acompanhar o curso devido a fragilidade da formação anterior; concluir o curso e descobrir que pouco ou quase nada foi agregado de valor à formação, devido à qualidade do curso; não conseguir inserir-se profissionalmente no mercado de trabalho; e, finalmente, não conseguir a melhoria da qualidade de vida que tanto desejava. (OLIVEIRA; BITTAR, 2010, p. 07)

Portanto, é inegável que aquele que tem uma jornada dupla, de estudante e trabalhador, tem que se esforçar muito mais para fazer um curso com qualidade, de modo a superar as dificuldades que terá que enfrentar, principalmente em termos de tempo de dedicação aos estudos, e qualidade desse tempo.

Nessa direção, este estudo evidencia que os estudantes, sobretudo os trabalhadores, dedicam poucas horas para o estudo extra, como demonstrado no gráfico abaixo: 
GRÁFICO 4: Quantas horas extra, por semana, você se dedica aos estudos?

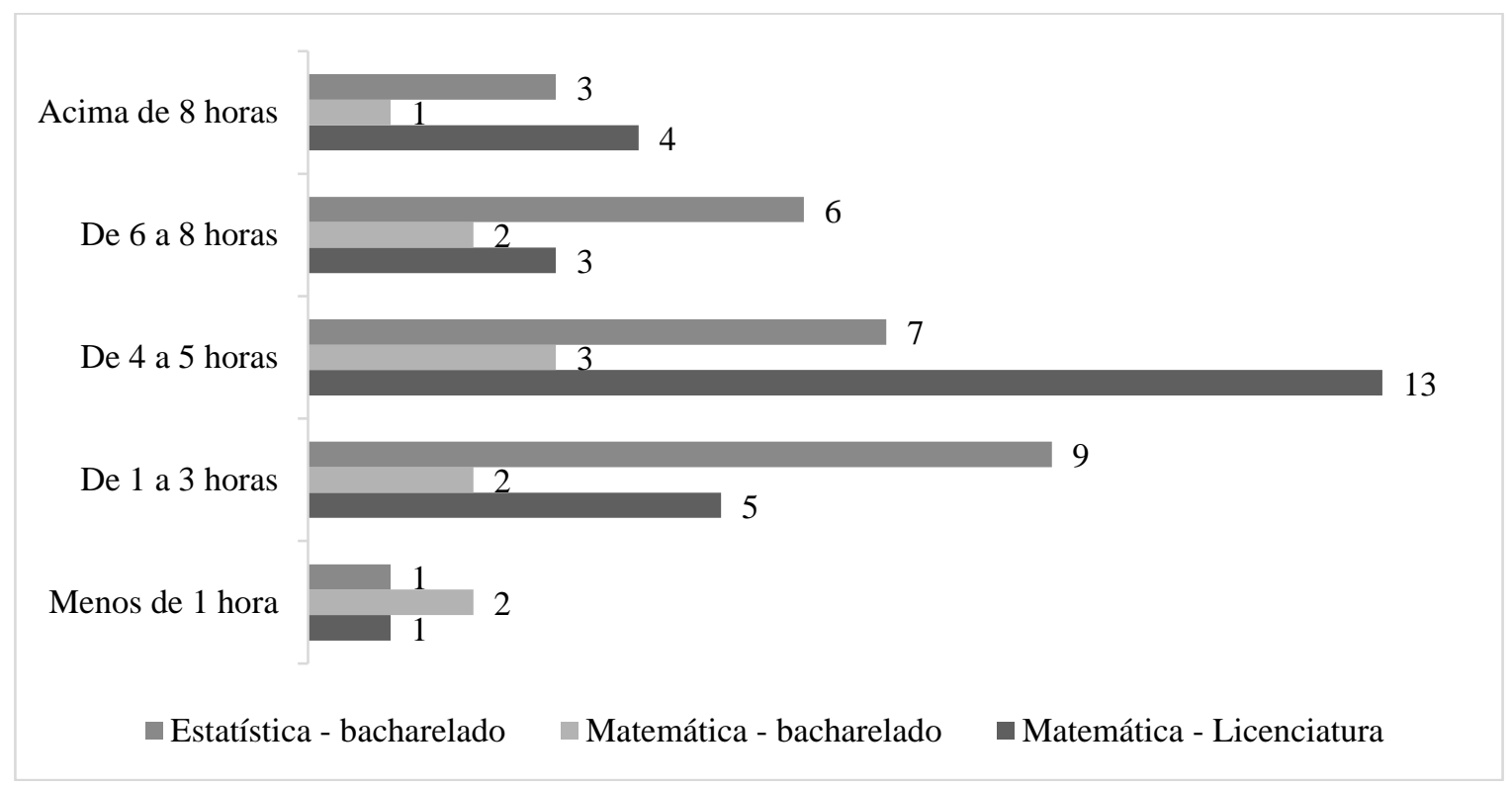

Fonte: Os autores

Dos 62 estudantes do IME/UFG participantes da pesquisa, apenas $12,9 \%$ afirmaram se dedicar mais de 8 horas semanais extra aos estudos, o que significa pouco mais de 1 hora e meia por dia útil, desconsiderando-se o final de semana. $17,7 \%$ afirmaram estudar entre 6 e 8 horas; $37,1 \%$ de 4 a 5 horas; $25,8 \%$ de 1 a 3 horas; e 6,5\% menos de 1 hora por semana. Portanto, a maior parte dos alunos da unidade declarou dedicar aproximadamente 1 hora por dia aos estudos $(37,1 \%)$ e, na sequência, apareceu o grupo que se dedica apenas de menos de 1 a 3 horas semanais $(32,3 \%)$.

Dos alunos da Estatística - bacharelado, $34,6 \%$ disseram se dedicar de 6 a mais de 8 horas semanais aos estudos, o que é a quantidade de tempo mais razoável. No curso de Matemática bacharelado, esse percentual foi de apenas $30 \%$, e na Matemática - licenciatura de 26,9\%. Logo, no panorama geral, os alunos da Estatística bacharelado foram os que destinaram mais tempo para o estudo extraclasse.

Fica evidente que é muito pouco o tempo destinado ao estudo extraclasse, considerando a complexidade de um curso de graduação, quantidade de disciplinas que normalmente são cursadas por semestre, e tendo em vista o grau de abstração de algumas disciplinas da área de Matemática; bem como a necessidade de conhecimento em programação, no caso do curso de Estatística.

Também é necessário ressaltar que, além de não se dedicarem ao estudo extraclasse, a procura pelos professores fora do horário das aulas, com o objetivo de sanar dúvidas dos conteúdos das disciplinas, não é uma rotina para a maior parte dos estudantes do IME/UFG. No conjunto dos 62 alunos que responderam ao questionário, $46,8 \%$ afirmaram que procuram os professores para atendimento fora do horário de aula. Os alunos do curso de Estatística - bacharelado são os que mais têm esse hábito, pois, dos 26 respondentes, 53,8\% afirmaram que o fazem. Já no curso de Matemática, tanto no bacharelado como na licenciatura, a maioria é de alunos que não procuram os professores para sanar dúvidas. No bacharelado, apenas $40 \%$ disseram que fazem isso, e na licenciatura $42,3 \%$. Portanto, esse contato e aproximação com os professores deve ser uma prática estimulada.

Segundo o Dicionário Aurélio Online, atender significa: ter em consideração; cuidar de; deferir; estar com atenção. Portanto, o horário de atendimento é um momento de escuta mais íntima e próxima, em que o professor está à disposição para ouvir o seu aluno de forma mais individualizada, e, assim, compreender quais são as suas dificuldades, os seus problemas, mas também suas potencialidades. Por conseguinte, o aluno que usufrui desse momento tem muito a ser beneficiado, pois tem a oportunidade de ser melhor acolhido, orientado, ajudado.

Mas, assim como não procuram os professores para sanar suas dúvidas, há um número considerável de alunos do IME/UFG que não 
participam de nenhuma atividade acadêmica além das aulas, como demonstrado no gráfico abaixo:

GRÁFICO 5: Você participa de alguma atividade acadêmica além das aulas ? ${ }^{5}$

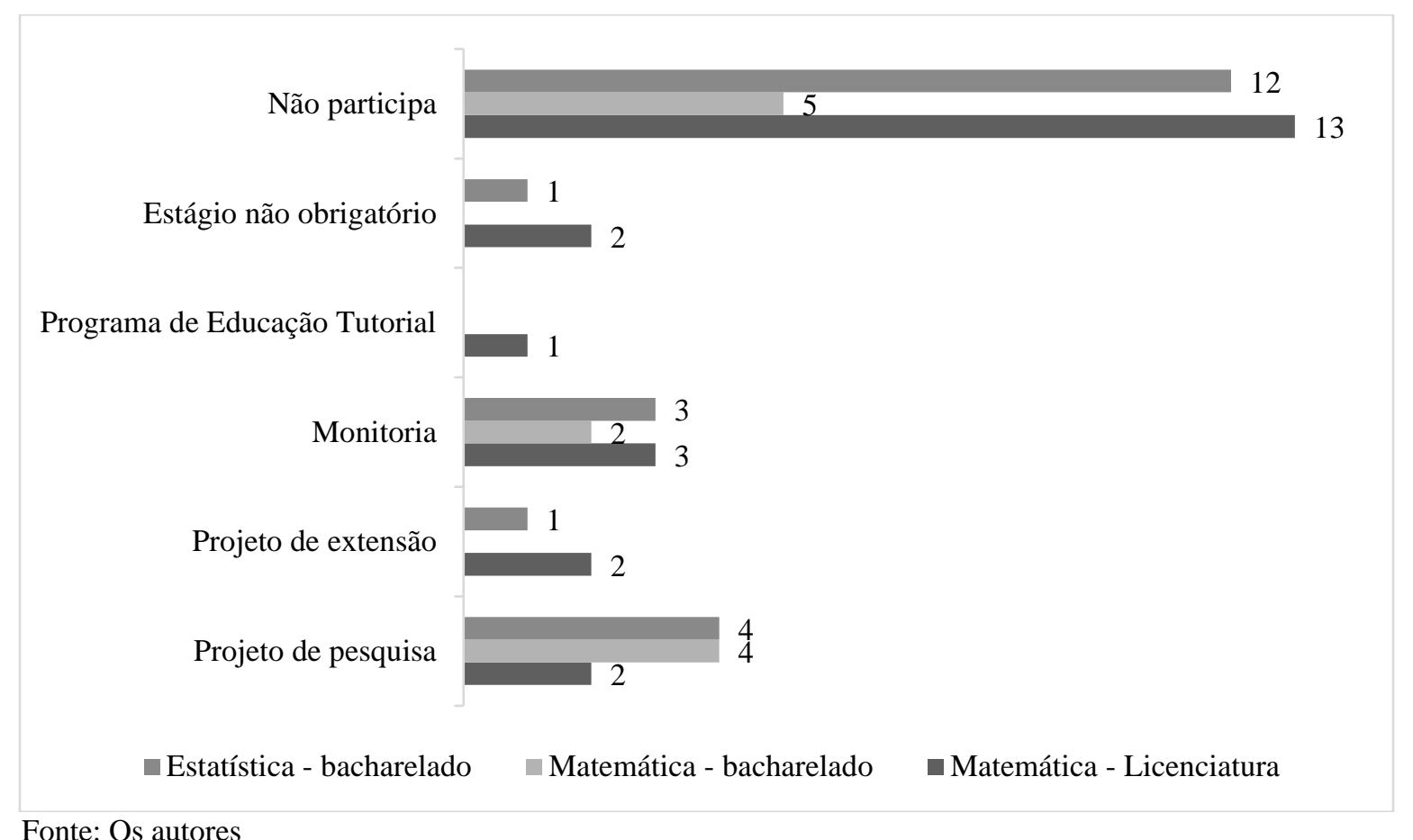

Fonte: Os autores

Das 55 respostas a essa questão, ficou claro que $54,5 \%$ declararam não participar de nenhuma atividade acadêmica extraclasse. Além desses, três alunos disseram fazer estágio não obrigatório $(5,5 \%)$, um participar do Programa de Educação Tutorial (PET) $(1,8 \%)$, oito da Monitoria $(14,5 \%)$, três de projetos de extensão $(5,5 \%)$ e dez de projetos de pesquisa $(18,2 \%)$.

Também vale observar que, dos 23 alunos da Matemática - licenciatura, além dos 56,5\% que afirmaram não participar de nenhuma atividade, três deles declararam estar envolvidos na Monitoria $(13,1 \%)$, dois no estágio não obrigatório $(8,7 \%)$, dois em projetos de extensão $(8,7 \%)$, dois em projetos de pesquisa $(8,7 \%)$ e um no PET $(4,3 \%)$. Já dos 11 alunos da Matemática - bacharelado que responderam essa questão, $45,5 \%$ disseram não participar de nenhuma atividade, dois da Monitoria $(18,2 \%)$ e quatro de projetos de pesquisa $(36,3 \%)$. Logo, é evidente que os alunos do bacharelado não estão envolvidos no PET, tampouco em projetos de extensão, que são atividades mais voltadas para alunos da licenciatura, que lidam diretamente com a educação, e realizam projetos extensionistas voltados sobretudo para a educação básica. Como ficou evidente, o foco do bacharelado é a pesquisa, o que justifica o envolvimento dos graduandos desse curso principalmente em projetos dessa natureza.

Já dos 21 alunos da Estatística - bacharelado que responderam a essa questão, 57,1\% declararam não participar de nenhuma atividade extracurricular, quatro de projetos de pesquisa (19\%), três da Monitoria $(14,3 \%)$, um de estágio curricular não obrigatório $(4,8 \%)$ e também um único aluno de projeto de extensão $(4,8 \%)$. No curso em questão, não houve aluno participante do PET, por se tratar de um programa voltado especificamente para os graduandos da licenciatura em Matemática. Exceto isso, os alunos da Estatística estão envolvidos nas diversas atividades acadêmicas, que não somente as aulas.

Santos e Silva (2011) afirmam que:

Quanto mais tempo passar o estudante nesse ambiente [acadêmico], maiores serão suas chances de compreender o funcionamento desse mundo, suas regras, seus limites, suas exigências e possibilidades. Mesmo a participação em eventos não diretamente relacionados às 
aprendizagens acadêmicas é importante nesse percurso que leva da admissão ao diploma. (SANTOS; SILVA, 2011, p. 257)

Nessa direção, entende-se como primordial incentivar e buscar formas de promover o envolvimento máximo do aluno na universidade, seja por meio da participação em projetos, eventos científicos, ou mesmo estimulando o contato com os professores, em uma relação mais próxima. Para tanto, a universidade prevê que na estrutura curricular do Projeto Político do Curso (PPC) constem as atividades complementares, juntamente com as disciplinas e estágios. Porém, a maioria dos alunos se limita a participar de atividades complementares que sejam suficientes para cumprir a carga horária prevista para cada curso.

Além do que foi apresentado, para compreender os fatores que levam os alunos do IME/UFG a prolongarem o tempo de graduação, é preciso analisar o desempenho acadêmico dos mesmos, o que, neste caso, é expresso pela quantidade de reprovações que os mesmos têm nas disciplinas do curso.

GRÁFICO 6:Quantas reprovações você teve?

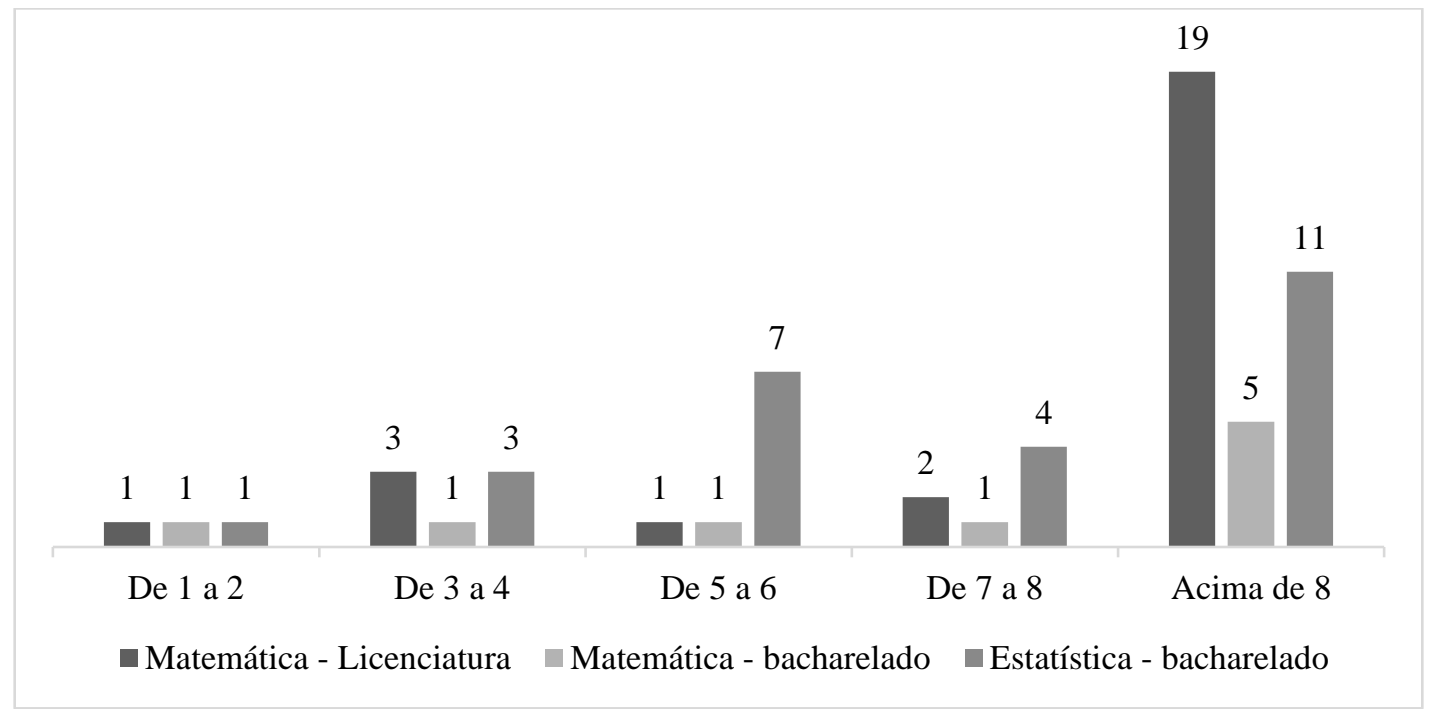

Fonte: Os autores

Dos 61 alunos que responderam a essa questão, 57,4\% afirmaram que já tiveram acima de 8 reprovações no decorrer do curso, o que é um número bastante expressivo. Além desses, 11,5\% declararam ter tido de 7 a 8 reprovações; $14,7 \%$ de 5 a 6 reprovações; $11,5 \%$ de 3 a 4 reprovações; e 4,9\% de 1 a 2 reprovações. Assim sendo, é notório que um dos fatores responsáveis pelos alunos permanecerem mais tempo que o previsto para a conclusão do curso é o excesso de reprovações.

Também é importante ressaltar que os alunos da Matemática - licenciatura são os que mais sofreram muitas reprovações. Dos 26 alunos retidos do curso que participaram da pesquisa, $73,1 \%$ tiveram mais que 8 reprovações no decorrer da trajetória acadêmica. Já dos alunos da Matemática bacharelado, o percentual de alunos com esse número de reprovações foi 55,5\%; e no curso de Estatítica - bacharelado de $42,3 \%$. Portanto, este estudo aponta para a necessidade de uma avaliação do panorama de reprovação extrema na Matemática - licenciatura. Isso pode estar acontecendo em razão do pouco tempo que os alunos desse curso se dedicam aos estudos, visto que a grande parte trabalha o dia todo? $\mathrm{Ou}$ seria pelas deficiências de aprendizado não sanadas desde a educação básica? Vale refletir.

No mais, Silva Filho (2009) afirma que a permanência prolongada na graduação pode estar relacionada às reprovações ocorridas principalmente no primeiro ano de curso, e que esse fenômeno pode influenciar na decisão pelo abandono definitivo do mesmo. Isso porque, a reprovação, por si só, é um indicativo de que o estudante enfrenta problemas, e, se não houver uma intervenção por parte da instituição, a consequência é o abandono.

É importante dizer que as reprovações 
podem estar relacionadas a diversos fatores, mas um

atribuída ao curso. aspecto extremamente significativo é a dificuldade

GRÁFICO 7: Qual grau de dificuldade você atribui ao curso?

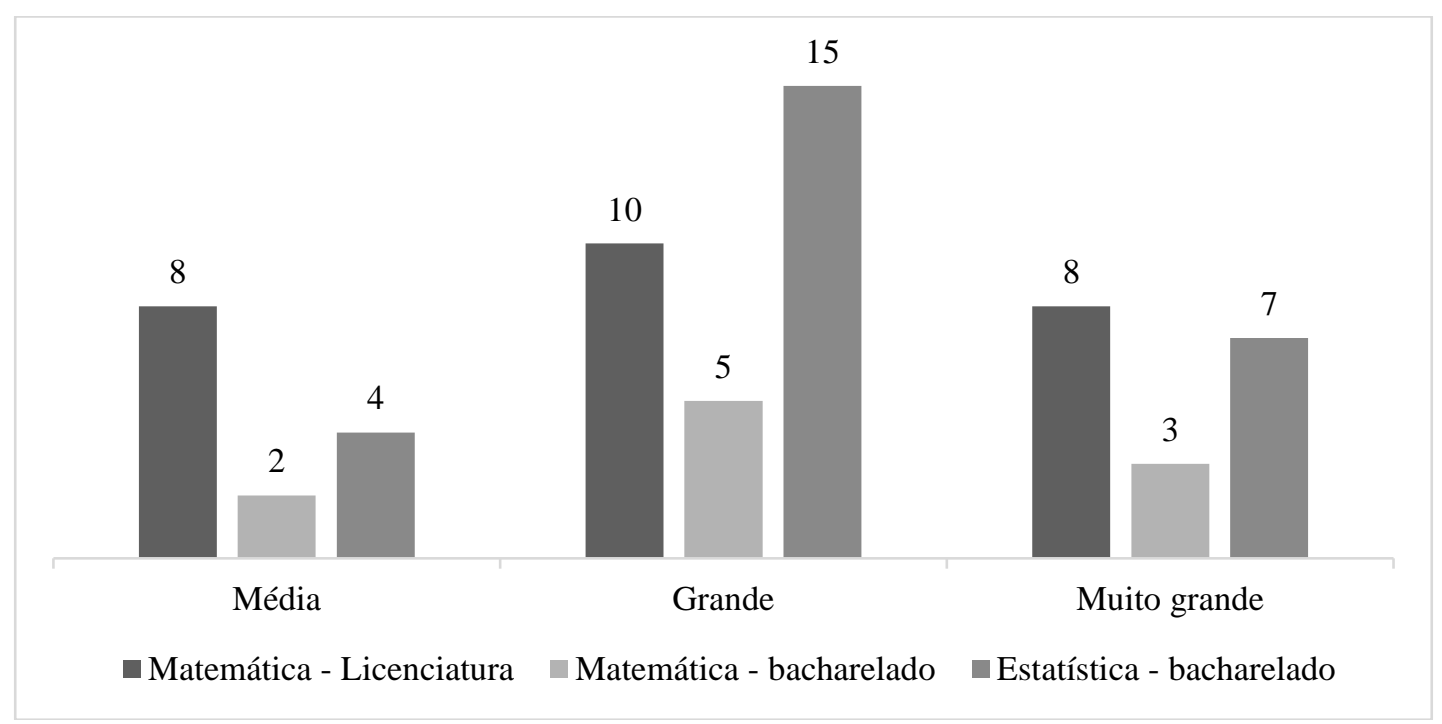

Fonte: Os autores

Do grupo de alunos investigados, 29\% atribuíram grau de dificuldade muito grande ao curso que frequentam; 48,4\% grande; e 22,6\% média. Nenhum dos alunos indicou o intem dificuldade pequena, o que leva a entender que os cursos do IME/UFG não são fáceis. Dos alunos da Matemática - licenciatura, 69,2\% atribuíram dificuldade de grande a muito grande ao curso, e apenas $30,8 \%$ média. Já dos alunos da Matemática - bacharelado, $80 \%$ consideraram a dificuldade grande ou muito grande, e apenas $20 \%$ média. E do grupo de estudantes da Estatítica - bacharelado, 84,6\% afirmaram que a dificuldade do curso é de grande a muito grande, e $15,4 \%$ média.

Logo, pela percepção dos alunos, o curso mais difícil do IME é o de Estatística - bacharelado. Entretanto, mesmo os alunos desse curso o entendendo como difícil, eles apresentem um percentual de muitas reprovações menor que o dos demais cursos ofertados pela unidade. Isso pode ser explicado pelo fato de que são esses os alunos que mais procuram os professores fora das aulas para tirar suas dúvidas. Além disso, outro fator que pode influenciar esse quadro é o maior tempo dedicado aos estudos, que ocorre com os alunos da Estatística bacharelado em detrimento dos outros estudantes do IME/UFG.

Pelo exposto, acredita-se que "O acompanhamento acadêmico e pedagógico adequado, ao longo do curso, pode auxiliar no desempenho dos alunos com déficit de aprendizado bem como auxiliar os que têm outras dificuldades". (SILVA, 2016, p. 85) Diante dessa necessidade de melhorar o desempenho acadêmico dos alunos, o que a autora propõe é a estruturação do sistema de monitorias com vistas a conter a retenção, e, logo, a evasão ocasionada por baixo rendimento acadêmico. Silva (2016) faz o diagnóstico de que:

Apesar da divulgação sistemática das monitorias, é alto o número de alunos que, apesar de estar repetindo a disciplina, não procuram a monitoria. [...] Cabe ressaltar que outro fator que interfere na eficiência da monitoria é a falta de regularidade em que os alunos procuram atendimento. [...] percebe-se que o período de maior procura é aquele que antecede o dia da prova ou de entrega do trabalho. (SILVA, 2016, p. 85-86)

Essa realidade é muito similiar a que acontece no IME/UFG. Portanto, deve-se trabalhar em prol de um sistema de Monitoria mais eficiente, que realmente promova melhoria no desempenho acadêmico dos estudantes que dela participem. Por isso, a unidade em questão está trabalhando em uma proposta de reconfiguração da Monitoria, descentralizando-a do simples atendimento aos 
alunos que desejam tirar dúvidas, ou de resolução de exercícios. A proposta é que sejam ministradas, pelos professores que se voluntariem, em parceria com os monitores, "aulas" sobre conteúdos elementares para o desempenho das disciplinas, ou mesmo sobre conteúdos de matemática básica, nos quais os estudantes apresentam fragilidade em termos de conhecimento. Além disso, entende-se como fundamental a melhor divulgação dessa atividade, visto que é pouco o número de alunos que participa da mesma.

Quando se trata de prolongamento de curso, também é razoável verificar se o trancamento do curso é fator determinante.

GRÁFICO 8:Você trancou o curso por quantos períodos?

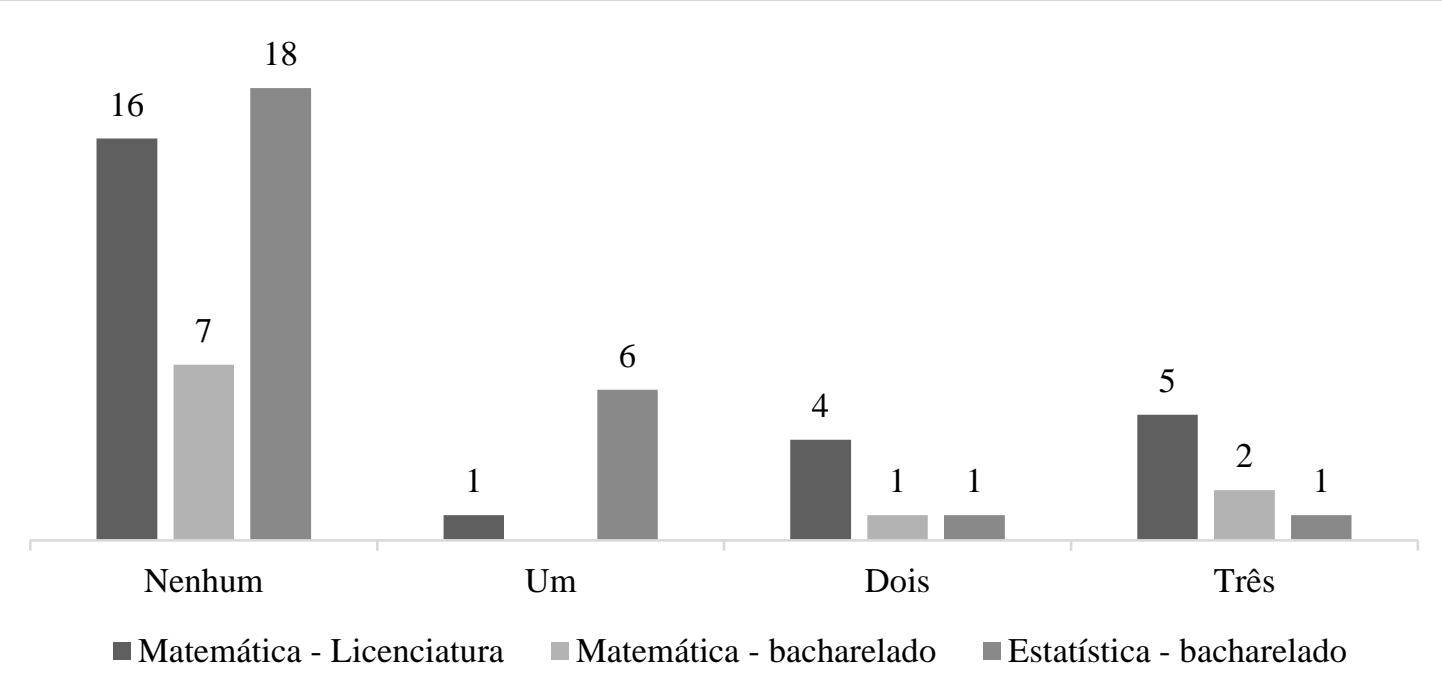

Fonte: Os autores

É interessante demarcar que, do total de 62 participantes da pesquisa, grande parte, o que representa $62,1 \%$, disse que nunca trancou o curso; $11,3 \%$ realizou apenas um trancamento; $9,7 \%$ dois; e $12,9 \%$ três. Mas, mesmo não sendo significativo o número de reprovações, Polydoro (2010) ressalta a necessidade de um olhar especial da instituição de ensino para esse estudante em situação de trancamento, para que se possa buscar informações sobre a integração à universidade, bem como sobre as ações voltadas para a superação de dificuldades envolvidas na decisão pelo trancamento. É preciso compreender quais são os fatores que levam à interrupção temporária do curso, o que, para alguns, pode acarretar em evasão definitiva.

Polydoro (2010) mostra, em seu estudo, que apenas $9,62 \%$ dos alunos em situação de trancamento de matrícula retomaram os estudos no período letivo imediatamente posterior. No mais, identificou que o trancamento foi o responsável por mais da metade das evasões definitivas do curso. Daí entende-se o trancamento como decisivo na decisão por abandonar a graduação.

Além do elevado número de reprovações e trancamentos de curso, outros fatores podem ser decisivos na retenção dos alunos nos cursos. Por isso, buscou-se compreender quais dificuldades os alunos mais enfrentam na sua trajetória acadêmica. 
GRÁFICO 9: Quais dificuldades você enfrenta no curso ${ }^{6}$

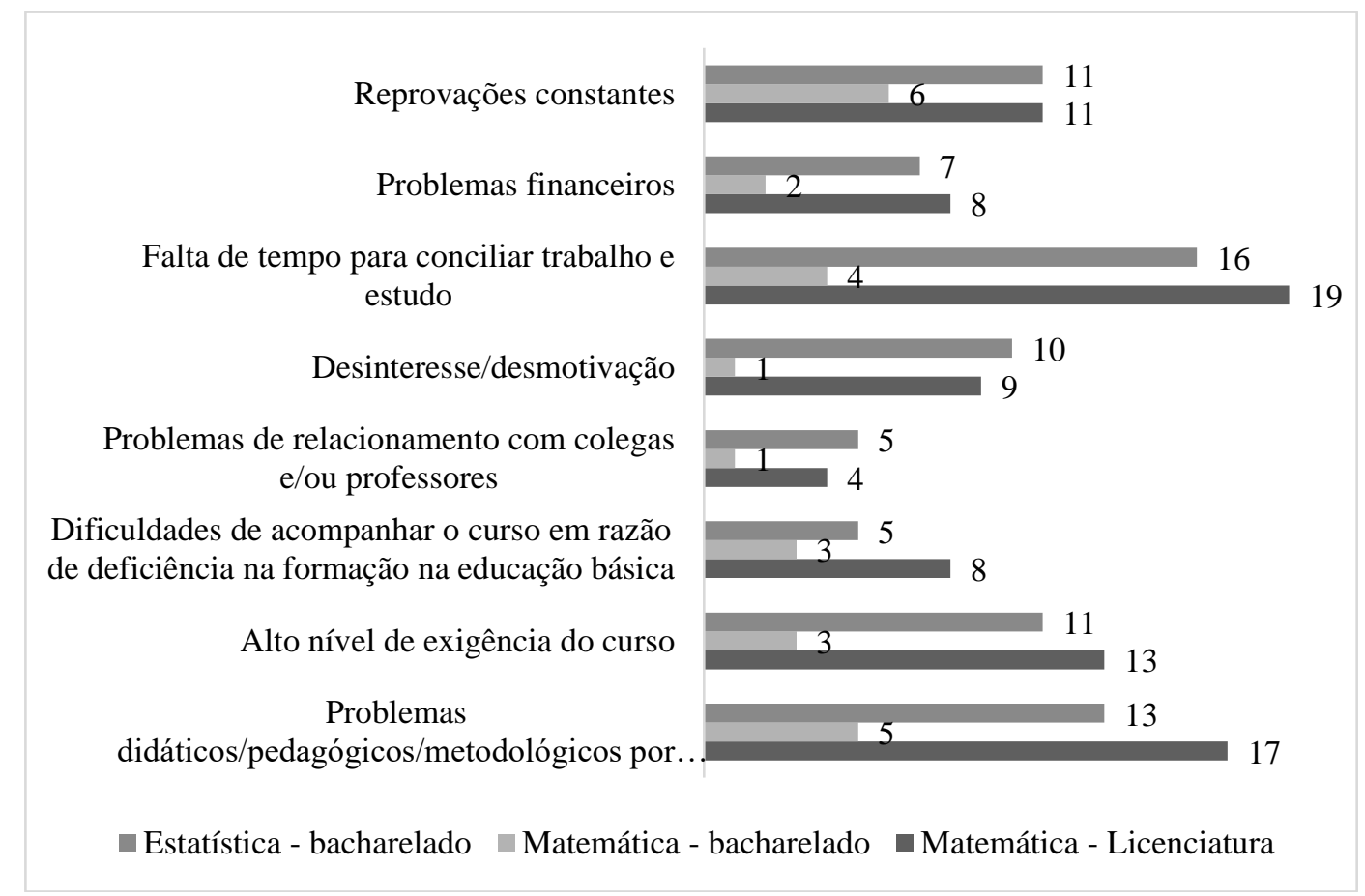

Fonte: Os autores

Os fatores elencados como dificuldade pelos alunos nas 192 respostas apareceram na seguinte ordem: falta de tempo para conciliar trabalho e estudo (20,3\%), problemas didáticos/pedagógicos/metodológicos por parte dos professores $(18,2 \%)$, reprovações constantes $(14,6 \%)$, alto nível de exigência do curso $(14,1 \%)$, desinteresse/desmotivação $(10,4 \%)$, problemas financeiros $(8,9 \%)$, dificuldades de acompanhar o curso em razão de deficiência na formação na educação básica $(8,3 \%)$ e problemas de relacionamento com colegas e/ou professores $(5,2 \%)$. Nenhum desses aspectos pode ser considerado quando se pensa nas razões que levam os alunos a enfrentar dificuldades no decorrer do curso. Contudo, os que mais apareceram em suas repostas merecem uma atenção especial.

No caso da dificuldade de conciliar trabalho e estudo, o fator mais citado, entende-se que " $O$ trabalho, buscado por esses jovens como um fator de autonomia e/ou independência econômica em relação a suas famílias, concorre fortemente com a obtenção de um diploma, fragilizando suas trajetórias acadêmicas". (SANTOS; SILVA, 2011, p. 256) A decisão por trabalhar leva a uma situação adversa, visto que os alunos reconhecem a relevância da trajetória escolar, tanto para a formação intelectual como para a mobilidade social, mas sentem a necessidade de trabalhar para manter suas condições básicas de vida, o que dificulta a dedicação aos estudos.

Outro problema evidente se refere às práticas didáticas/pedagógicas/metodológicas dos professores. "Infelizmente ainda temos instituições que seguem, ainda que não declaradamente, os preceitos da pedagogia tradicional, centrados na figura do professor e que pouco incentiva a interação entre aluno, professor e conhecimento". (SANTO; LUZ, 2013, p. 69) Esse fato aponta para a necessidade de rever a preparação pedagógica dos docentes da educação superior, posto que sua prática interfere no desempenho dos estudantes.

Logo, é dever da universidade investir na formação continuada do seu quadro docente. A preocupação das instituições de educação superior não deve ser exclusivamente com os docentes que acabaram de ingressar da universidade, com os "novos professores", mas também com aqueles que já estão há vários anos exercendo a docência, e que precisam refletir sobre sua prática, sua posição, seu desempenho. Por assim ser, é imprescindível a criação de uma estrutura que fomente a formação contínua do quadro de docentes, que promova momentos de ensino e aprendizagem também para aqueles que ensinam. 


\section{Considerações Finais}

Este estudo evidenciou um elevado percentual de alunos retidos no IME/UFG. E entre as características desses alunos em situação de prolongamento de curso, $43 \%$ não estão matriculados no curso que realmente desejavam, o que é bastante representativo. $\mathrm{O}$ desejo, em grande parte, era por cursos de maior prestígio. Porém, a escolha foi condicionada principalmente por aptidões e interesses pessoais, nos cursos de Matemática, e por expectativas em relação ao mercado de trabalho, no curso de Estatística. $\mathrm{O}$ estudo também mostrou que, apesar de não terem ingressado no curso que pretendiam como primeira opção, os estudantes não apresentam intenção de mudar de curso, ou mesmo de desistir, talvez, por já estarem em um nível de adiantamento do curso.

$\mathrm{O}$ estudo também apontou que o perfil socioeconômico dos alunos retidos do IME/UFG é de vulnerabilidade socioeconômica. Em razão disso, muitos desses estudantes são trabalhadores, e, logo, enfrentam dificuldade de conciliar o trabalho com os estudos. Como consequência, esses alunos se dedicam poucas horas extra semanais aos estudos, e também não têm muita participação em atividades acadêmicas extraclasse, o que compromete o rendimento acadêmico. Prova disso é que o número de reprovações, considerando o grupo dos alunos excluídos, é muito representativo, posto que $57,4 \%$ afirmaram ter mais de 8 reprovações ao longo do curso.

Esse panorama de insucesso acadêmico é atribuído a diversos fatores, mas, principalmente, falta de tempo para conciliar trabalho e estudo; problemas didáticos/pedagógicos/metodológicos por parte dos professores; reprovações constantes; e alto nível de exigência do curso. Os alunos também consideram o nível de dificuldade dos cursos do IME/UFG variando de médio a muito grande, o que pode influenciar nas dificuldades enfrentadas no decorrer da trajetória acadêmica.

Registra-se que este estudo busca compreender os contornos da retenção no IME/UFG. Mesmo assim, representa um recorte, baseado em escolhas feitas pelos pesquisadores. Dessa forma, para uma compreensão mais detalhada do fenômeno em questão, fica patente a necessidade de desenvolvimento de mais estudos, principalmente, dando voz aos alunos. É pela percepção dos alunos retidos que se pode entender, de fato, quais são os motivadores do prolongamento do curso. E apenas dessa forma é possível desenvolver ações, criar políticas que minorem o quadro de retenção das instituições de ensino.

No campo da educação profissional e tecnológica, há um "Documento orientador para a superação da evasão e retenção na Rede Federal de Educação Profissional, Científica e Tecnológica", publicado pela Secretaria de Educação Profissional e Tecnológica do Ministério da Educação (MEC), em 2014. Esse documento foi proposto tendo como fundamento a necessidade de "[...] um olhar sobre a qualidade do ensino, o atendimento à diversidade, a permanência e o êxito dos estudantes no processo educativo". (MEC, 2014, p. 04) O documento contempla um plano de ação composto por sete dimensões, entre elas o entendimento dos fenômenos da evasão e retenção e medidas para o seu combate.

Diante disso, acredita-se que a educação superior deve se inspirar nessas medidas já adotadas em outros níveis e modalidades de educação, e desenvolver ações concretas para a compreensão e combate ao fenômeno da retenção, que é um dos grandes responsáveis pela evasão nas universidades brasileiras. Logo, estudos com a natureza deste que foi aqui apresentado, que mapeiam as razões que levam os alunos a atrasarem a conclusão dos seus cursos de graduação, são elementares para fornecer subsídios para intervenção efetiva e eficaz nessa problemática.

E uma das medidas primordiais para isso é o acompanhamento acadêmico do estudante, desde seu ingresso no curso. A partir de um contato mais próximo e de um olhar mais cuidadoso ao aluno que ingressa na educação superior, é possível compreender quais dificuldades ele enfrenta para concluir seu curso. Dessa maneira, é possível atuar de maneira mais rápida e eficaz na resolução desses problemas, e, assim, evitar que o aluno leve a situação de vulnerabilidade adiante. Quanto antes o aluno receber apoio ou orientação, menores serão as chances de ele prolongar o seu curso, ou desistir do mesmo.

Destarte, é preciso atuar em várias frentes, monitorando os alunos com vistas a encaminhá-los para acompanhamento pedagógico, médico, psicológico, ou mesmo assistência socioeconômica. É fundamental que o aluno perceba que a universidade dispõe de uma rede de apoio para auxiliá-lo quando dificuldades de diversas ordens se fizerem presentes, tolhendo o andamento de sua trajetória acadêmica. Portanto, a primeira medida necessária é o acompanhamento do aluno ingressante. 


\section{Notas}

1 Para o curso de Matemática, o prazo de integralização regular é de oito semestres, e para o curso de Estatística, de nove semestres.

2 Não há alunos ingressantes antes de 2008 retidos no IME/UFG, por isso a tabela é construída somente a partir dessa data.

3 Nesta questão, os alunos podiam marcar mais de uma alternativa. Porém, o que se verificou é que houve apenas 41 respostas, menos que os 62 participantes da investigação, de modo que nem todos responderam a esse item.

4 Segundo critério utilizado pelo Instituto Brasileiro de Geografia e Estatística (IBGE), a classe social, de acordo com a renda familiar, é a seguinte: $\mathrm{A}=$ acima de vinte salários mínimos; $\mathrm{B}=$ entre dez e vinte salários mínimos; $\mathrm{C}=$ entre quatro e dez salários mínimos; $\mathrm{D}=$ entre dois e quatro salários mínimos; e $\mathrm{E}=$ até dois salários mínimos.

5 Nesta questão, os alunos podiam marcar mais de uma alternativa. Porém, o que se verificou é que houve apenas 55 respostas, menos que os 62 participantes da investigação, de modo que nem todos responderam a esse item.

6 Nesta questão, os alunos podiam marcar mais de uma alternativa. Houve 192 respostas, portanto, os alunos indicaram mais de um item em suas respostas.

\section{Referências}

BARDAGI, Marucia Patta; HUTZ, Claudio Simon. "Não havia outra saída": percepção dos alunos evadidos sobre o abandono do curso superior. PsicoUSF, v. 14, n. 1, p. 95-105, jan./abr. 2009.

CAMPELLO, Antonio de Vasconcellos Carneiro; LINS, Luciano Nadler. Metodologia de análise e tratamento da evasão e retenção em cursos de graduação de institutos federais de ensino superior. In: XXVIII Encontro Nacional de Engenharia de Produção, 2008, Rio de Janeiro. Anais... Rio de Janeiro, 2008.

DICIONÁRIO ONLINE DE PORTUGUÊS. Disponível em: https://www.dicio.com.br/. Acesso em: 19 out. 2017.

DICIONÁRIO DO AURÉLIO. Disponível em: https://dicionariodoaurelio.com/atender. Acesso em:
27 nov. 2017.

GONDIM, Sônia M. G. Grupos focais como técnica de investigação qualitativa: desafios metodológicos. Paidéia, Ribeirão Preto, v. 12, n. 24, p. 149-161, 2002.

LIMA JÚNIOR, Paulo; SILVEIRA, Fernando Lang; OSTERMANN, Fernanda. Análise de sobrevivência aplicada ao estudo do fluxo escolar nos cursos de graduação em Física: um exemplo de uma universidade brasileira. Revista Brasileira de Ensino de Física, v, 34, n. 1, 2012.

MINISTÉRIO DA EDUCAÇÃO. Secretaria de Educação Profissional e Tecnológica. Documento orientador para a superação da evasão e retenção na Rede Federal de Educação Profissional, Científica e Tecnológica. Brasília: MEC, 2014.

OLIVEIRA, João Ferreira; BITTAR, Mariluce. Ensino superior noturno no Brasil: democratização do acesso, da permanência e da qualidade: In: I Congresso Ibero-Brasileiro, VI Congresso LusoBrasileiro, VI Congresso do Fórum Português, 2010, Elvas (Portugal). Anais... Elvas (PT) Rio de Janeiro: Anpae, 2010.

PEREIRA, Alexandre Severino et al. Fatores relevantes no processo de permanência prolongada de discentes nos cursos de graduação presencial: um estudo na Universidade Federal do Espírito Santo.

Ensaio: aval. pol. públ. Educ., Rio de Janeiro, v. 23, n. 89, p. 1015-1039, out./dez. 2015.

PEREIRA, Alexandre Severino. Retenção discente nos cursos de graduação presencial da UFES. Dissertação de mestrado. Programa de PósGraduação em Gestão Pública. Universidade Federal do Espírito Santo, 2013.

POLYDORO, Soely Aparecida Jorge. $O$ trancamento de matrícula na trajetória acadêmica universitária: condições de saída e de retorno à instituição. 2010. 175 p. Tese de doutorado. Faculdade de Educação. Universidade Estadual de Campinas, Campinas/SP, 2010.

SANTO, Eniel do Espírito; LUZ, Luiz Carlos Sacramento da. Didática no ensino superior: perspectivas e desafios. Saberes, Natal, v. 1, n. 8, p. 58-73, ago. 2013. 
SANTOS, Georgina Gonçalves; SILVA, Lelia Custódio. A evasão na educação superior: entre debate social e objeto de pesquisa. In: SAMPAIO, S. M. R. (Org.). Observatório da vida estudantil: primeiros estudos. Salvador: EDUFBA, 2011.

SILVA, Fernanda Cardoso da. $O$ desempenho acadêmico e o fenômeno da evasão em cursos de graduação da área da saúde. 2016. 138 p.

Dissertação de mestrado. Programa de PósGraduação em Ciências e Tecnologias em Saúde. Universidade de Brasília, 2016.

SILVA FILHO, José Pereira. As reprovações em disciplinas nos cursos de graduação da Universidade Federal do Ceará (UFC) no período de 2000 a 2008 e suas implicações na evasão discente. 2009.71 p. Dissertação de mestrado. Mestrado em Políticas Públicas e Gestão da Educação Superior. Universidade Federal do Ceará, 2009.

VANZ, Samile Andrea de Souza et al. Evasão e retenção no curso de Biblioteconomia da UFRGS. Avaliação, Campinas; Sorocaba, v. 21, n. 2, p. 541568, jul. 2016.

VIEIRA, Eduardo Tadeu. Índices de retenção na Universidade de Brasília: abordagem do ponto de vista do financiamento. 2013. 181 p. Tese de Doutorado. Faculdade de Economia, Administração e Contabilidade. Universidade de Brasília, 2013.

\section{Sobre os autores}

Chaiane de Medeiros Rosa é técnica em assuntos educacionais. Possui Pós-Doutorado em Educação na Universidade Estadual Paulista (Unesp), câmpus Araraquara (2017) e doutorado em Educação Escolar pela mesma instituição (2016). É mestra em Educação pela Universidade Federal de Goiás (UFG), câmpus Catalão (2013) e graduada em Licenciatura Plena em Letras - Português pela mesma instituição (2009). É técnica em assuntos educacionais na UFG Regional Goiânia.

Fabiano Fortunato Teixeira dos Santos é professor na graduação. Doutor em Matemática pela Universidade de Brasília (UnB) (2011). Mestre em Matemática pela Universidade Federal de Goiás (UFG), câmpus Goiânia (2002). Graduado em Licenciatura em Matemática, pela Universidade Federal de Uberlândia (UFU) (1998). É docente no Instituto de Matemática e Estatística (IME) da UFG.

Recebido em novembro de 2017.

Aprovado em fevereiro de 2018. 